\title{
Peluang baru keberterimaan Barat atas syariah Islam
}

\author{
Abdul Aziz Nugraha Pratama \\ STAIN Salatiga, Jl. Tentara Pelajar No. 02 Salatiga \\ E-mail : pratama_abdul@yahoo.com \\ Judul : Membumikan Syariah, Pergulatan Mengaktualkan Islam \\ Pengarang : Mohammad Hashim Kamali \\ Penerbit : Noura Books (PT Mizan Publika) \\ Tahun terbit : 2013 \\ Tebal : viii +442
}

\section{Pendahuluan}

"Orang yang tidak mau mendasarkan negara itu kepada hukum-hukum Islam dengan alasan tidak mau merusakkan hati orang yang beragama Islam, sebenarnya (dengan tidak sadar atau memang disengaja) telah berlaku zalim kepada orang Islam sendiri yang bilangannya di Indonesia 20 kali lebih banyak, lantaran tidak menggugurkan sebagaian dari peraturan-peraturan agama mereka (agama Islam). Ini berarti merusakkan hak-hak mayoritas, yang sama-sama hal itu tidak berlawanan dengan hak-hak kepentingan minoritas, hanya semata-mata lantaran takut, kalau si minoritas itu "tidak doyan". Ini namanya "staatkundige", demokrasi tunggang balik."

Allabyarbam Mohammad Natsir, tokoh Partai Masyumi

"Sebagai Muslim, janganlah kita melalaikan hukum Allah. Sebab, di awal surah Al-Maaidah sendiri yang mula-mula diberi peringatan kepada kita ialah supaya menyempurnakan segala 'uqud (janji). Maka, menjalankan hukum Allah adalah salah satu 'uqud yang terpenting diantara kita dengan Allah. Selama kita hidup, selama iman masih mengalir di 
seluruh pipa darah kita, tidaklah boleh sekali-kali kita melepaskan cita-cita agar hukum Allah tegak di dalam alam ini, walaupun di negeri mana kita tinggal. Moga-moga tercapai sekadar apa yang kita dapat capai. Karena Tuhan tidaklah memikulkan beban kepada kita suatu beban yang melebihi dari tenaga kita. Kalau Allah belum jalan, janganlah kita berputus asa. Dan kufur, zalim, fasiklah kita kalau kita percaya bahwa ada hukum yang lebih baik daripada hukum Allah. Jika kita yang berjuang menegakkan cita Islam ditanya orang, 'Adakah kamu, hai umat Islam bercita-cita, berideologi, jika kamu memegang kekuasaan, akan menjalankan hukum syariat Islam dalam negara yang kamu kuasai itu? Janganlah berbohong dan mengolok-olokkan jawaban. Katakan terus terang, bahwa cita-cita kami memang itu. Apa artinya iman kita kalau cita-cita yang digariskan Tuhan dalam Al-Qur'an itu kita pungkiri?

Dan kalau ditanya orang pula, tidaklah demikian dengan kamu hendak memaksakan agar pemeluk agama lain yang digolongkan kecil (minoritas) dipaksa menuruti hukum Islam? Jawablah dengan tegas, "Memang akan kami paksa mereka menuruti hukum Islam. Setengah dari hukum Islam terhadap golongan pemeluk agama yang minoritas itu ialah agar mereka menjalankan hukum Taurat, ahli Injil diwajibkan menjalankan hukum Injil. Kita boleh membuat undang-undang menurut teknik pembikinannya, memakai fasal-fasal dan ayat suci, tapi dasarnya wajiblah hukum Allah dari Kitab-kitab Suci, bukan hukum buatan manusia atau diktator manusia. Katakan itu terus terang, dan jangan takut! Dan insaflah bahwa rasa takut orang menerima hukum Islam ialah karena propaganda terus menerus dari kaum penjajah selama beratus tahun. Sehingga, orang-orang yang mengaku beragama Islam pun kemasukan rasa takut itu...”

Hamka, Tafsir Al-Azhar, Juz 6

Kutipan di awal artikel ini merupakan petikan pernyataan penting dari dua tokoh Muslim dan negarawan Indonesia, yakni Mohammad Natsir dan Buya HAMKA tentang Syariat Islam. Keduanya memberikan nasehat kepada mereka yang "takut atau terkesan malu-malu" untuk menegakkan Syariat Islam.

Bagi pegiat di bidang syariah (baca juga: Hukum Islam), khususnya yang pro kepada penegakan syariat Islam, perbincangan yang mengasumsikan bahwa watak syariah atau hukum Islam itu bersifat dinamis (lawan dari statis), luwes (lawan dari kaku), dan rahmatan lil 'alamin adalah sesuatu yang sudah mafhum. Namun bagi kubu penentang pemahaman tersebut, mengasumsikan bahwa syariah atau hukum Islam itu telah beku, usang dan tidak layak di jaman yang sudah jauh dari awal kemunculannya. Padahal Hukum Islam sangat sesuai dengan 
kondisi di mana ia berlaku dan berkembang.

Hingga saat ini, seringkali kemunculan wacana untuk mengaplikasikan Hukum Islam masih dianggap sebagai momok yang mengkhawatirkan, bahkan menakutkan. Dan patut disayangkan ketika para ahli besar Syariah sering terlihat tidak siap untuk menyampaikan nuansa dan asal-usul diskursus Islam yang fundamental kepada pendengar yang lebih luas. Sementara itu, di Barat muncul suatu sudut pandang xenofobik yang hendak menempatkan Syariah menjadi suatu gagasan lintas sejarah yang membatu dan selamanya bertentangan dengan kesetaraan gender, demokrasi, dan hal itu (agaknya) berada di pusat kesadaran Barat. Jarang sekali ada sarjana yang bisa berbicara dengan otoritas dan pemahaman mendalam mengenai Syariah kepada pendengar luas. Sampai hadir Mohammad Hashim Kamali (hal. v).

Buku Membumikan Syariah, Pergulatan Mengaktualkan Islam yang diterjemahkan dari Shariah law, An Introduction karya M. Hashim Kamali ini dimaksudkan untuk mengungkap kembali secara komprehensif asal-usul Syariah dalam Al-Qur'an dan hendak mencoba menjelaskan posisi dan arti sebenarnya 'Syariah' dalam ajaran Islam. Kamali menggambarkan bahwa Joseph Schacht yang sudah meninggal tahun 1969 pernah mendeskripsikan Syariah dengan penjelasan yang salah. Menurut Kamali, Schacht telah mendeskripsikan Syariah sebagai inti atau hakikat dari agama dan esensi Islam itu sendiri. Hal tersebut berakibat pada kecenderungan anggapan dengan mereduksi Islam hanya sebagai ajaran yang melingkupi seperangkat aturan hukum. Maka bagi Kamali, hal tersebut sangatlah berlebihan dan tidak memiliki dasar dalam al-Qur'an dan Sunnah (Kamali, 2008:3).

Dr. Mohammad Hashim Kamali adalah Ketua Pendiri dan CEO dari International Institute of Advanced Studi Islam (IAIS) Malaysia . Dia adalah anggota Constitution Review Commission of Afghanistan (2003), Penasihat Senior PBB pada reformasi konstitusi di Maladewa (2004), penasehat konstitusi Irak (2005) dan saat ini bekerja pada konstitusi baru Somalia. Dr. Hashim Kamali sangat dicari sebagai seorang ahli dalam reformasi konstitusi, hukum Islam dan Timur Tengah. Latar belakangnya dalam hukum positif berarti bahwa ide-idenya yang paling utama pragmatis. Dia adalah seorang sarjana yang sangat langka yang memimpin kehormatan di kedua kalangan Barat dan Muslim. Benar-benar berakar dalam tradisi tekstual klasik dan Arab, kata-katanya membawa bobot di kalangan umat Islam; dan pengetahuan tentang sejarah hukum dan konstitusi Eropa dan Amerika berarti bahwa ia berbicara kepada 
ljtihad, Jurnal Wacana Hukum Islam dan Kemanusiaan, Volume 14, №. 1, Juni 2014: 139-148

keprihatinan kontemporer Barat. Dia adalah Guru Besar Hukum dan Yurisprudensi Islam di International Islamic University Malaysia (1985-2004), dan juga Dekan International Institute of Islamic Though and Civilisation (ISTAC) dari 2004 sampai 2006. Dr. Kamali adalah seorang Profesor di Universitas Capital, Ohio, dan juga di Institute for Advanced Study (Wissenschaftskolleg) dari Berlin.

Dia melayani di dewan 13 jurnal akademik lokal dan internasional. Profesor Kamali telah mengikuti lebih dari 150 konferensi nasional dan internasional, dan dia telah menerbitkan 20 buku dan lebih dari 140 artikel akademis. Buku-bukunya antara lain: Principles of Islamic Jurisprudence (Prinsip fikih Islam); A Textbook of Hadith Studies (Textbook Studi Hadis); dan Freedom of Expression in Islam (Kebebasan Berekspresi dalam Islam); dan Shariaah Law: An Introduction (Hukum Syariah : Sebuah Pengantar) adalah referensi kerja di universitas berbahasa Inggris terkemuka di seluruh dunia.

Reputasi dan karya Kamali tersebut akan memungkinkan para pembaca memberikan penilaian tersendiri atas buku ini.

\section{Antara syariah, hukum Islam, dan fikih}

Di dalam kepustakaan hukum Islam berbahasa Inggris, Syari'at Islam diterjemahkan dengan Islamic Law, sedang Fikih Islam diterjemahkan dengan Islamic Jurispudence. Di dalam bahasa Indonesia, untuk syari'at Islam, sering, dipergunakan istilah hukum syari'at atau hukum syara' untuk fikih Islam dipergunakan istilsh hukum fikih atau kadang-kadang Hukum Islam (Faiz,2001:171).

Di buku Kamali dan buku lain, berbagai pakar, khususnya yang menekuni hukum Islam, telah memberikan definisi hukum Islam, yyariah, dan fikih. Diantara definisi tersebut diuraikan berikut ini :

1. Menurut Joseph Schacht (1964:1), Hukum Islam (Islamic Law) merupakan perintahperintah suci dari Allah Swt. yang mengatur seluruh aspek kehidupan setiap Muslim. Melalui penelitian sejarah yang empiris, Joseph Schacht menyebut Islamic Law sebagai ringkasan dari pemikiran Islam, manifestasi way of life Islam yang sangat khas, dan bahkan sebagai inti dari Islam itu sendiri. 
2. S.D. Goiten (1960:23) menyatakan bahwa Hukum Islam di samping merupakan perintahperintah suci dari Allah Swt. yang mengatur seluruh aspek kehidupan setiap Muslim, juga meliputi materi-materi-materi hukum secara murni serta materi-materi spiritual keagamaan.

3. Omid Safi (hal. v) menyatakan di Kata Pengantar buku karya Hashim Kamali, bahwa istilah Syariah sering diterjemahkan sebagai "hukum Islam".

4. Hashim Kamali (hal.19) mengartikan syariah secara harfiah berarti titian menuju sumber air, yang jelas untuk diikuti dan harus dijalani oleh orang beriman guna mendapatkan panduan di dunia ini dan keselamatan di akhirat.

5. Fikih adalah adalah istilah padanan Syariah dan keduanya sering digunakan bergantian; namun kedua kata ini tidak identik. Jika syariah disampaikan terutama melalui wahyu yang terkandung dalam al-Qur'an dan hadis sahih, maka fikih terutama merujuk pada corpus juris yang dikembangkan oleh berbagai mazhab, para fuqaha dan hakim, penggunaan penalaran hukum (ijtihäd) dan pemberian pendapat hukum (fatwa) (hal. 5).

Dengan menyimak definisi tentang hukum Islam dan atau Syariah serta fikih, sebagaimana diuraikan di atas, maka dapat kita simpulkan bahwa para pakar Barat (saat itu) nampak kurang tepat dalam mendefinisikan hukum Islam atau Syariah (Islam). Mereka menganggap bahwa hukum Islam atau syariah (Islam) itu adalah inti dari ajaran Islam. Padahal hukum Islam atau syariah yang sebenarnya, sebagaimana dikemukakan Hashim Kamali, adalah "hanya" sebagian dari ajaran Islam secara keseluruhan. Bahkan sebagian besar isi al-Qur'an, yakni 85 dari 114 surat, diturunkan di Makkah dan semuanya fokus pada Islam sebagai keyakinan dan struktur nilai-nilai moral (hal. 7).

Dr. Ali Mabrook, Guru Besar Filsafat Islam Cairo University menyatakan bahwa tidak akan pernah mungkin untuk menyatukan antara fikih dan syari'ah. Pasalnya fikih bersifat humanistic (insani) yang dipengaruhi kondisi dan tradisi masyarakat, sedangkan syari'ah bersifat teosentris (ilahi). Nah, kalau ada tuntutan penerapan syariah Islam di suatu negara, maka yang terjadi sebenarnya adalah penyempitan makna syari'ah.

Menurut Kamali, istilah Syariat sendiri tidak pernah digunakan oleh para Khulafa' Rasyidun sepeninggal Nabi, dan mereka tidak juga menggunakan fikih dalam maknanya sebagai kitab hukum. Peristilahan tersebut muncul jauh belakangan dan terutama terdiri dari ketentuanketentuan hukum yang baru diterima ketika fikih dikembangkan dalam rentang waktu yang 
ljtihad, Jurnal Wacana Hukum Islam dan Kemanusiaan, Volume 14, №. 1, Juni 2014: 139-148

lama (hal. 8). Dia juga menyatakan bahwa identifikasi Syariah sebagai tatanan hukum dan unsur penentu masyarakat dan Negara Islam, yang lalu menjadi lazim dalam tulisan-tulisan fikih yang muncul kemudian, tidak memiliki pijakan yang kuat dalam sumber-sumber Islam. Menurutnya pula, Islam yang utama dan terutama adalah keimanan dan tatanan moral; ia berdiri di atas kelima pilarnya, dan mengikuti kitab hukum adalah hal yang relatif dan subsider dibandingkan seruan dan pesan awal Islam. Karena itu, kata Kamali, penekanan pada legalisme yang selama ini mendominasi tradisi fikih Islam dan Syariah perlu diperlunak. Prinsip tawhid sebagai hal yang utama dalam Islam memerlukan pendekatan nilai yang terpadu dan tidak sepatutnya ditempatkan di bawah rubrik legalitas yang berfokus pada perilaku eksternal, dan seringkali dengan mengorbankan perkembangan diri manusia.

Pendapat Kamali di atas nampak begitu lugas dan seperti tidak terduga. Hal tersebut mengingat bahwa selama ini fikih dan syariah selalu dianggap sebagai bagian utama dalam ajaran Islam. Karena pemahaman yang demikian di sebagian besar ummat Islam, berakibat perbedaan yang berujung perpecahan. Mereka seringkali mempertahankan pendapat sesuai pemahaman diri dan kelompoknya hingga "titik darah penghabisan".

Karenanya, Kamali melalui buku ini hendak menawarkan sebuah rekaman perdebatan tentang Syariah dan pelaksanaannya di berbagai jaman dan tempat. Dengan bahasa yang sederhana dan contoh-contoh aktual, Kamali juga membawa pembaca ke dalam kajian tentang hakikat Syariah dan kaidah-kaidahnya, serta ijtihad para ulama di sepanjang jaman tanpa terjebak ke dalam semangat sektarian (lihat: back cover).

Kata Syariah dalam al-Qur'an digunakan sebagai lawan kata hawa. Definisi Syariah, yang sering digunakan dalam makna umum, yang mencakup tidak hanya hukum dalam al-Qur'an dan sunnah namun juga aturan-aturan rinci fikih yang telah dikembangkan oleh para ahli hukum dan ilmuwan melalui tafsir dan ijtihad. Namun lebih khusus lagi, Syariah didasarkan pada hukum-hukum dalam al-Qur'an dan Sunnah, berbeda dari fikih yang merupakan konstruksi hukum. Alur diskusi ini kemudian diikuti oleh pemaparan sumber-sumber Syariah di bawah tiga judul utama yakni al-Qur'an, Sunnah, dan ijtihad. Sisa bab ini membahas maksud dan tujuan atau maqāsid, Syariah yang dijabarkan dengan aturan-aturan rinci syariah dalam berbagai cabangnya. Maka pemahaman tentang maqāsid menjadi penting untuk mendapatkan wawasan mendalam mengenai Syariah. Syariah sering dideskripsikan sebagai 
keragaman dalam kesatuan-keberagaman penafsiran masing-masing faqih dan mazhab yang telah menjadi ciri khas Syariah, dan kesatuan maksud dan tujuan yang diikuti dengan penjabaran hukumnya. Melalui kesadaran akan maksud dan tujuan Syariah inilah kesatuan Syariah dilindungi dan ditegakkan.

Para sarjana di jaman sekarang merasa agak terkekang dalam mengupayakan rekonstruksi hukum dan ijtihad di tengah-tengah arus perubahan sosial yang begitu deras .(hal. 48).

\section{Jatidiri syariah}

Syariah adalah hukum ilahiah yang memiliki validitas permanen, yang juga merupakan menifestasi pandangan monoteisme (tawhid) dalam rumusan-rumusan yuristiknya. Syariah juga hendak melindungi kontinuitas maupun perubahan seperti halnya ia juga menyediakan mekanisme bagi kebertautan antara wahyu dan nalar dalam perumusan aturan-aturannya. Diskusi buku Kamali tentang masalah ini diikuti oleh satu bagian singkat tentang aspek lahiriah dan niat, di mana konformitas yang kaku pada aturan yang terlepas dari niat dan maksud hukum tidaklah dianjurkan. Keterputusan semacam ini sesekali juga ditemukan dalam bagian-bagian tertentu fikih, seperti akal-akalan hukum (al-hiyal), yang sudah jelas bermasalah, dan tempatnya dalam pemikiran fikih harus dikurangi seminim mungkin.

Perbedaan pendapat yuristik (ikhtilaff) merupakan ciri khas Syariah sekaligus disiplin akademis dan salah satu cabang Syariah. Fakultas Hukum Universitas Islam Malaysia, contohnya menawarkan satu mata kuliah studi ikhtiläf. Lawan kata ikhtiläa adalah konsensus umum (ijma) dan Kamali membahas peran dan nilainya masing-masing dalam perkembangan hukum Islam. Ijtihad serta ikhtiláf sama-sama merupakan sisi yang bernilai, bahkan keniscayaan, dalam hukum Islam. Namun, hari ini kita barangkali hidup dalam periode sejarah yang lebih menekankan perlunya konsensus ketimbangan perbedaan. Terlihat seolah-olah j̈tihad di masa lalu digunakan sebagai instrumen perbedaan pendapat daripada persatuan dan konsensus. Saat ini konsensus yang lebih besar lebih disarankan, bahkan barangkali menjadi keharusan bagi bangkitnya kembali Syariah dan ijtihad dan peran yang hendak dimainkan dalam hukum dan pemerintahan kontemporer di masyarakat Muslim.

Kamali juga menyoroti problematika ijtihad dan fatwa di masa modern. Keduanya, menurut Kamali, berperan penting dalam menghubungkan sumber-sumber daya Syariah 
ljtihad, Jurnal Wacana Hukum Islam dan Kemanusiaan, Volume 14, №. 1, Juni 2014: 139-148

kepada persoalan kontemporer, namun kegunaanya tehambat oleh beberapa kekurangan yang perlu diatasi terlebih dahulu. Ijtihad dapat berupa penafsiran baru atas teks dalam kaitannya dengan persoalan-persoalan tertentu yang belum pernah ditemui sebelumnya. Ijtihad dapat juga berupa langkah-langkah di luar penafsiran dengan menerapkan satu atau beberapa doktrin yang ada, seperti analogi (qiy ās), pertimbangan kepentingan publik (istișlāhọ), preferensi yuristik (istīsāan) dan seterusnya yang sesungguhnya merupakan sub-varian ïtihad dan dirancang untuk member pendekatan terstruktur dan metodologi. Fatwa biasanya terdiri atas responsrespons fuqaha terhadap suatu pertanyaan, saran yang bisa berupa jawaban ringkas, persetujuan atau ketidaksetujuan, bisa menyerupai ijtihad atau berada di bawah tingkatan itu. Bab ini diakhiri dengan pemaparan tentang problematika fatwa di masa modern dan member beberapa usulan untuk pembaruan.

Kamali juga menekankan tentang Syariah dan Prinsip Legalitas yang menggali syaratsyarat dasar prinsip legalitas dalam hukum modern dan sejauh mana hal ini bisa diterapkan dalam syariah. Prinsip legalitas, yang juga dikenal dengan prinsip supremasi hukum (atau juga dikenal dengan taat aturan/due process) pada intinya dipandu oleh gagasan pemerintahan di bawah supremasi hukum dan ia berlaku pada hampir semua bidang hukum yang hendak melindungi warga Negara dari penggunaan kekuasaan sewenang-wenang. Prinsip ini secara natural menjadi penting dalam lingkup hukum pidana, penangkapan, interogasi dan proses beracara dalam persidangan, dan bab ini mengangkat ketiga persoalan tersebut dalam kaitannya dengan Syariah dan sejauhmana ia dapat sesuai dengan prinsip legalitas konsitusional.

\section{Ketika syariat Islam bersinggungan dengan demokrasi}

Ketika membahas "Demokrasi, Hak-hak Fundamental dan Syariah", Kamali juga mengetengahkan pandangan tentang seberapa jauh keharmonisan dapat dicapai antara postulat-postulat dasar demokrasi dan Syariah. Diangkatnya pula, fenomena meningkatnya dukungan bagi demokrasi di antara partai-partai dan gerakan Islam dan meningkatnya kehadiran mereka dalam politik electoral khususnya sejak 1999 di Timur Tengah, Turki, Pakistan, Indonesia, dan Malaysia.

Terminologi-terminologi keadilan, shürā, ijma', ikhtiläf, bay'ah, dan mașlặah (kepentingan publik) telah memberi kerangka dasar bagi demokrasi Islami.(hal. 293). Hal tersebut 
nampaknya sejalan dengan hipotesis yang dikemukakan Saiful Mujani (2007: 32-34) yang bertolak belakang dengan pandangan para pakar Barat semisal Samual P. Huntington, yang mengemukakan beberapa hipotesis berikut ini: Hipotesis pertama, semakin Islami, semakin kecil keterlibatannya dalam kegiatan masyarakat yang bersifat sekuler. Kedua, semakin Islami, semakin tidak toleran ia terhadap kelompok lain (terutama yang berbeda keyakinan). Ketiga, semakin Islami semakin jauh ia terlibat dalam politik (demokrasi). Keempat, semakin Islami maka akan semakin tidak percaya ia terhadap institusi demokrasi. Hipotesis kelima, semakin Islami, semakin besar pula penolakan atas prinsip demokrasi. Keenam, semakin Islami, semakin ia tidak mendukung negara bangsa sebagai sebuah komunitas politik (karena Islam lebih mengenal konsepsi ummah). Ketujuh, semakin Islami semakin ia tidak berpartisipasi dalam politik kecuali politik itu terkait dengan tuntutan agama. Kedelapan, semakin Islami semakin kecil kemungkinan ia menjadi warga yang setia (tertarik pada politik dan percaya pada institusi politik demokrasi). Hipotesis terakhir, seorang Muslim yang tidak toleran akan cenderung aktif dalam politik.

Dengan menggunakan metode survei opini publik, Saiful Mujani (2007: 313-324) menemukan sejumlah kesimpulan: Pertama, Islam di Indonesia mempunyai keterlibatan dalam kegiatan kewarganegaraan sekuler. Ibadah sunnah di NU, identitas ke-Muhammadiyah-an dan jaringan keterlibatan dalam perkumpulan sesama Muslim, justru memperkuat keterlibatan orang dengan kegiatan yang bersifat sekuler. Kedua, keterlibatan umat Islam di Indonesia dalam kegiatan keagamaan dan sekuler membuat umat Islam toleran terhadap kelompok lain. Ketiga, umat Islam di Indonesia justru memberikan kontribusi positif bagi munculnya partisipasi demokrasi. Keempat, umat Islam yang saleh di Indonesia tidak mengancam konsolidasi demokrasi. Ada sejumlah nilai dalam Islam yang diyakini mendukung demokrasi, yakni melalui ijtihad (penalaran rasional), ijma (konsensus), ikhtiläf (perbedaan pendapat), dan shürā (konsultasi). Saiful Mujani menyimpulkan, korelasi negatif antara Islam dengan prinsip demokrasi meragukan. Muslim di Indonesia sangat mendukung negara bangsa. Konsepsi tentang ummah tidak otomatis bertentangan dengan gagasan negara bangsa. Unsurunsur ibadah dalam Islam justru makin memperkuat keterlibatan umat Islam di Indonesia dengan berbagai masalah masyarakat, tak hanya yang terkait dalam urusan agama. Dalam hipotesis kedelapan, Saiful menemukan tak ada kaitan antara keimanan seorang Muslim 
ljtihad, Jurnal Wacana Hukum Islam dan Kemanusiaan, Volume 14, №. 1, Juni 2014: 139-148

dengan ketertarikan dengan politik dan kepercayaan terhadap institusi politik. Terakhir, Islamisme yang bersifat intoleran tak terkait dengan aktifitas politik. Seorang Muslim yang intoleran justru cenderung tidak aktif dalam politik dan bukan merupakan ancaman bagi demokrasi.

Penelitian tersebut dapat merefleksikan nuansa baru perpolitikan Negara dengan penduduk yang mayoritas merupakan Muslim. Kondisi demikian ini akan menumbuhkan peluang baru keberterimaan Barat atas syariah Islam. Syariah Islam tidak selalu menjadi momok menakutkan bagi siapapun, terutama masyarakat Barat yang selama ini memberinya cap miring. Syariat Islam tidak selalu vice a vice dengan demokrasi. Dan kondisi umat Muslim Indonesia bisa menjadi “dirijen” yang lihai mengarahkan keterpaduan Syariah dan demokrasi dalam kehidupan bernegara.

\section{Daftar pustaka}

Faiz, Maksun. Konstitusional Hukum Islam dalam Sistem Hukum Nasional, Membedab Peradilan Agama. Semarang: PPHIM Jawa Tengah, 2001.

Goitein, S.D., "The Birth-Hour of Muslim Law; an Essay in Exegesis" The Muslim World, vol. L (1960).

http://www.eraMuslim.com/manhaj-dakwah/fikih-siyasi/pesan-buya-hamka-dan-mnatsir-jangan-takut-menegakkan-syariat-islam.htm\#.U3Rli9KQb2o

http://www.uinsby.ac.id/index.php/18-uinsa/news/110-tidak-mungkin-enyatukan-konsepsyariah-fiqh-penerapan-syari-ah-islam-di-negara-hanya-upaya-talbis

Kamali. Muhammad Hashim. Membumikan Syariah. Diterjemahkan oleh Miki Salman. Jakarta: Noura Books (PT Mizan Publika), 2013.

Mujani, Saiful. Muslim Demokrat: Islam, Budaya Demokrasi, dan Partisipasi Politik di Indonesia Pasca-Orde Baru. Jakarta: Gramedia Pustaka Utama, 2007.

Schacht, Joseph. An Introduction to Islamic Law, cet. II. Oxford: Oxford University Press, 1964. 